\title{
CEO Relative Compensation, Takeover Premium and Bidder Performance in Australia: Efficient Contracting or Managerial Power?
}

\author{
Hoa Luong \\ School of Accounting - Faculty of Business and Law \\ Curtin University \\ Email:hoa.luong@curtin..edu.au
}

John Evans

School of Accounting - Faculty of Business and Law Curtin University

Email: john.evans@curtin.edu.au

\section{Lien Duong}

School of Accounting - Faculty of Business and Law Curtin University

Email: 1.duong@curtin.edu.au

Submission for FMCG 2018 


\title{
CEO Relative Compensation, Takeover Premium and Bidder Performance in Australia: Efficient Contracting or Managerial Power?
}

\begin{abstract}
This paper analyses the impact of CEO relative compensation on takeover premiums and bidder's performance. Based on a sample of takeovers deal between Australian listed targets and bidders from 2000 to 2015, our findings reveal that bid premiums are higher if deals are conducted by CEOs with high relative compensation. The correlation between CEO relative compensation and bidder's announcement return is significantly negative, while its association with one year and two-year returns post takeovers are in an upward direction, which is in sharp contrary to the US and UK markets. We suggest the link between CEO relative compensation and CEO capacities, but not with the managerial power. Overall, our findings largely support the efficient contracting theory to have more explanatory power in the Australian context.
\end{abstract}

Key words: CEO relative compensation, takeover premium, bidders' performance, efficient contracting, managerial power

\section{INTRODUCTION}

There is a large body of literature in the area of corporate takeovers, the significant activities that help firms maintain and improve their competitiveness as well as adapt to market changes (Weston et al., 2003). However, whether CEO pays too much for acquisition and whether a bidder gains from a takeover is still debatable. Controversy also exists in specifying if CEO compensation is a product of optimal setting or managerial bias. Especially, it is argued that involving in takeover transaction may result in compensation increase and questions CEOs' incentive in making this investment decision (Grinstein and Hribar, 2004). Theories of merger drivers and manager contracting have been established to unfold features of mergers and acquisitions. The proponents of neoclassical theory argue that industry shocks and adequate funds are triggers of takeover deals (Mitchell and Mulherin, 1996; Jovanovic 
and Rousseau, 2002; Harford, 2005). In line with the neoclassical theory, the efficient contracting theory resists that CEO compensation presents the ability-matching arrangement and manager process a deal in the interest of the shareholders (Jensen and Meckling, 1976; Lazear and Rosen, 1981). Managerial theory or hubris hypothesis followers cite managerial incentive and behaviour to have the prominent impact on takeover activities (Roll, 1986; Scharfstein and Stein, 1990). Takeovers' expensiveness and bidders' performance with reference to CEO relative compensation have been evaluated by (Hayward and Hambrick, 1997), showing that CEO who earns higher relative compensation than his peers, being classified as overconfident, pays higher for a deal but his firm experiences poorer results than deals made by CEO with a low relative compensation. Bebchuk et al. (2011) contend that CEO relative compensation is an indicator of managerial power and lowers acquirer's returns. In short, the result of mergers and acquisition indicate the presence of optimal contracting or managerial power in the CEO relative compensation.

The motivation of this paper is threefold inspiring by the arguments of Finkelstein and Hambrick (1996) regarding the determinants of executive compensation. Firstly, the economic explanations for executive compensation relate managers' compensation to either corporate growth or profit maximisation. Thus we focus on assessing CEOs' relative compensation and the takeover outcomes, including bid premium and bidder performance, to clarify the underlying reasons for takeover decisions. Secondly, the social explanations for executive compensation center in CEOs' need to evaluate their own capacities, strategies and contributions and compare with others who are similar to some extent. As such, we contend that relative compensation is a relevant variable to reflect CEOs' abilities, incentives and behaviours. Thirdly, the political explanations for executive compensation cite managerial power to be a critical determinant of CEOs' pay. Hence, we propose that examining CEO relative compensation reveals the level of CEOs' managerial power.

Regarding the Australian market, bid premium has been analysed by a number of studies and bidder performance has been widely discussed. Duong and Izan (2012) report bid premium in relation to period of high concentrated takeover activities. Bugeja et al. (2016) test the influence of takeover method on the bid premium. Bugeja, Matolcsy, Mehdi, et al. (2017) examine the relation among takeover premium, 
abnormal returns and non-executive directors' compensation. Bugeja and Loyeung (2017) explore the association between takeover premium, accounting for business combination, IFRS adoption and CEO compensation structure. Regarding short-term performance of acquires, Walter (1984), Bugeja and Da Silva Rosa (2010) and Chan and Emanuel (2011) reveal negative announcement returns while Bishop et al. (1987), Simmonds (2004), Christopher and Zicheng (2008), Porter and Singh (2010), Shams et al. (2013) and Bugeja, Matolcsy, Mehdi, et al. (2017) confirm positive market reaction. Similarly, Walter (1984) suggest that takeovers are value enhancing for bidders in long-term while Da Silva Rosa and Walter (2004), Chan and Emanuel (2011) and Duong and Izan (2012) show evidence of value-decreasing deals. The linkage between CEO pay and firm performance also has been considered. Izan et al. (1998) present no evidence of the association, meanwhile Merhebi et al. (2006) prove that the relation is positive and significant. In another study, Rath (2007) believe that the CEO pay packages are appropriate and do promote CEO competence.

Nonetheless, the impact of CEO relative compensation on takeover premium and bidder performance remains an open question, given a number of distinct features between Australian context and the US and UK market has been deliberated. Australia has a smaller market for mergers and acquisitions with cash financed to be the main method of payment (Christopher and Zicheng, 2008; Duong and Izan, 2012). Australia is considered to maintain the "best practice" guidelines for corporate governance than other market (Kiel and Nicholson, 2003). The size of boards in Australia, on average, is smaller and the proportion of insiders on board is lower while CEO duality is much lower than in the United States (Kiel and Nicholson, 2003; Fernandes et al., 2013; Schultz et al., 2013). Henry (2008) specifies that there is also lower institutional ownership in Australia with large firms usually having a higher proportion of institutional ownership. In Australia, board size and board independence are positively related to firm size, while CEO duality is negatively related to firm size. In the United States, CEO duality is often seen in large firms (Hodne et al., 2013; Monem, 2013). Moreover, Australia differs from the US regarding the CEO employment contract and compensation (Matolcsy and Wright, 2007; Hill et al., 2011). Hill et al. (2011) reveal that, the American CEOs' total pay is higher in the US whereas in Australia, the base salary composition is greater and restriction on CEO's shares and derivatives hedging is tighter. Matolcsy and Wright (2007) add that there are greater variation in CEO 
option grant in Australia than in the US. Hence, this paper holds the same conjecture with Matolcsy and Wright (2007) that findings in other market may not be valid in the Australian context.

This paper firstly aims at classifying each CEO based on his relative remuneration in comparison with the average compensation of the board of directors. Secondly, we explore how high the offer price is if takeovers conducted by a CEO with a high (low) relative compensation. Thirdly, we analyse bidders' performance post takeover surrounding announcement and in one year and two years' time.

This paper makes two main contributions to the literature. Firstly, CEO relative compensation has been discussed in the mergers and acquisitions literature as an explanation for takeover consequences. It has been established that the ratio of CEOs' personal pay to that of other directors might unveil more prominent stimuli on CEOs' insights and behaviours than does the absolute compensation (Cropanzano et al., 2001). Finkelstein and Hambrick (1996) argue that one of the key factors of manager compensation is the relative power of CEO over the board of directors. However, previous studies in the US largely focus on the relative compensation between CEO and the second highest executive or the top five executives. One reason for this restriction may be the data unavailability (Siegel and Hambrick, 2005). In the US, compensation disclosure is applied for chief executive officer, chief financial officer and three other most highly compensated executive officers. ${ }^{1}$ In Australia, listed companied are required to disclose compensation of each director and each of the five officers with highest emolument. ${ }^{2}$ With that data obtainability, we suggest that comparing CEO compensation to the compensation of the board can be conducted in the Australian context. As such, this paper examines how does CEO relative pay to the average compensation of the board influence the acquisitions' outcomes. Secondly, to the best of our knowledge, this is the first study analyses the correlation between CEO relative compensation prior to the deal announcement with takeover premium and bidders' performance in the Australian market. Since acquisitions are driven not only by the macroeconomics but also by individual judgments (Cyert and March, 1963), given Australia distinguishes from the US and other countries in term of takeover

\footnotetext{
1 The particular rules for disclosure are set forth in the provisions of the SEC's Regulation S-K, specifically, Title 17 CFR 229.402 - Item 402 (Executive Compensation)

2 New section 300A of the Corporations Law, inserted by the Company Law Review Act 1998
} 
market and corporate governance practice, our findings differ from the findings presented the US market.

Our sample includes takeover deals between listed targets and bidders on the Australian Stock Exchange for the period from 2000 to 2015. We find that there are less deals announced by CEO with high relative compensation. We report higher, insignificant takeover premium offer by CEO with high relative compensation. Regarding the influence of CEO relative compensation, a sharp contrast with other market's finding has been evidenced. Our empirical test shows that although CEO with high relative compensation undergoes the unfavourable market reaction to the deal announcement, the acquiring firms will benefit from higher long-term returns. Our findings support the efficient contracting hypothesis in CEO remuneration, which opposes to the managerial power interpretation.

This paper is structured as follows. Section 2 reviews of the literature with reference to relevant theories. Section 3 discusses the methodology. Section 4 describes the sample selection. Section 5 presents the key findings and implications. Section 6 concludes the paper.

\section{LITERATURE REVIEW}

The efficient contracting hypothesis puts forward that traditionally, both of the supply and demand sides of the labour market drive CEO compensation, thus set CEO relative compensation at the optimal level. High CEO relative compensation is to honour CEO for higher skills and efforts devoting for the firm's operations in comparison with other top executives (Lazear and Rosen, 1981; Borokhovich et al., 1997). Financial market links CEO relative compensation with CEO's talent and contribution to firm value (Lazear and Rosen, 1981; Chang et al., 2010). As such, efficient contracting theory infers the appropriate takeover offer that CEO pay, not the expensiveness of the deal.

With regards to the association between CEO relative compensation and acquirers' performance, efficient contracting hypothesis reasons that high CEO pay disparity reduces monitoring costs for shareholders and the board. Thus, a departure of CEO remuneration from that of his peers creates mechanisms that better align principal-agent interests and motivate CEO towards value-enhancing decisions. As a 
result, high CEO relative compensation positively influences performance (Lee et al., 2008; Kale et al., 2009). The implication of the efficient contracting theory regarding bid premium and bidder performance is equivalent to that of the neoclassical theory.

The managerial power theory holds that manager incentive and power are determinant factors of CEO relative compensation (Hayward and Hambrick, 1997; Bebchuk and Fried, 2003). When the variance of CEO pay and that of his peer is greater, the CEO's sense of domination is revealed. Such a large disparity exposes CEO to believe that directors differ broadly in their abilities, contributions and that he is tremendously valued (Hambrick and Cannella, 1993). When there is the presence of CEO self-interest, the agency cost occurs in the form of CEO's rent extracting behaviour using his management power. As such, self-importance and private interest induce CEO to offer higher takeover premium (Roll, 1986; Hayward and Hambrick, 1997). Moreover, high CEO pay difference has been observed to be related with negative firm's performance in general (Core et al., 1999), and acquirer's returns in particular (Hayward and Hambrick, 1997; Bebchuk et al., 2011).

Whereas the relationship between CEO relative compensation prior to takeover announcement, bid premium and bidders' performance is observed in the US and UK markets, there is limited evidence on this correlation in the Australian market. Chalmers et al. (2006) suggest that CEO remuneration indicates firm's requirement of skilled CEO and the signal of rent extraction is insignificant. However, they do not investigate if the findings are applicable for bidding firms. Bugeja et al. (2012) find evidence of increasing impact of firm performance and CEO compensation post takeover but they do not consider the influence of CEO pay prior to the announcement. This has so far remained a gap in existing literature that this paper expects to fill in.

In general, judgments from prior research on the connection between CEO relative compensation, bid premium, and bidder performance are broadly divided. Our paper contributes to this debate by evaluating if (i) CEO relative compensation associates with the managerial power and value-destroying takeovers; or (ii) CEO relative compensation is a product of efficient contracting and results in valueenhancing transactions. We address three research questions: (i) how to rank high and low CEO relative compensation?; (ii) how do CEO relative compensation affect bid premium?; (iii) how do CEO relative compensation affect bidder performance post 
takeovers? Given a number of differentiates between Australia and other countries in term of takeover market and corporate governance practice, our findings will align each theory's implication with the Australian context.

\section{METHODOLOGY}

\subsection{Classifying High and Low CEO Relative Compensation}

Given the complexity of acquisition decision making, together with accounting for the underlying macroeconomic reason, decision maker's abilities or bias and limitation should be analysed. One of the most revealing proxy that incorporate manager's personality traits and power are his relative pay comparing with other directors (Frank, 1985). As such, CEO relative compensation can reveal more salient evidence of CEO's judgment and behaviour than his own remuneration (Wade et al., 2006). The underlying reason is if CEOs have confidence in their superior abilities, they would demand for greater pay disparity (Hayward and Hambrick, 1997). We examine CEO relative total compensation to the board average in the financial year prior to announcement. Both short-term and long-term components of compensation including salary, bonus, superannuation and non-pecuniary benefits, shares, stock options and other compensation are included except the final payout.

To classify high and low relative compensation, we compare the expected CEO relative compensation with the actual value using least square regression. This approach has been used to analyse CEO pay (Wade et al., 2006), CEO overpayment and underpayment (Fong, 2010), CEO relative standing (Seo et al., 2015) and excess CEO pay slice (Bugeja, Matolcsy, and Spiropoulos, 2017). Consistent with the literature, CEO relative compensation is estimated by controlling for firm's economic and corporate governance practices. The CEO relative compensation equation and control variables are specified as follow:

$$
\begin{aligned}
\text { CEORelComp }=\beta_{0}+ & \beta_{1 \text { TotalAssest }+\beta_{2} \text { SaleGrowth }+\beta_{3} \text { ROA }+} \\
& \beta_{4} \text { ShareReturns }+\beta_{5} \text { BoardSize }+\beta_{6} \text { InsiderRatio }+ \\
& \beta_{7} \text { CEODuality }+\beta_{8} \text { CEOTenure }+\beta_{9} \text { CEOownership } \\
& +\beta_{10} \text { CEORemuneration }+\beta_{11} \text { CEONomination }+ \\
& {[\text { Industry Dummies }]+[\text { Year Dummies }]+\varepsilon }
\end{aligned}
$$


The dependent variable, CEORelComp, is the ratio of CEO total compensation in the financial year prior to takeover announcement divided by the average compensation of the board of directors.

According to Holmstrom's "hidden action" model, manager's capacity are unobservable to the investors. As such, binding CEO remuneration to measurable variables is suggested to associate his salary with his responsibilities and behaviour (Hart and Holmstrom, 1986). In general, if the ratio represents a large proportion of CEO pay over the total compensation, it may capture either efficient contracting or managerial rent extracting, that both ultimately influence the operational monitoring mechanism and decision making process.

The first control group in model (1) are observable measurement interrelated with CEOs tasks. TotalAsset is the total book value of assets at the end of the financial year prior to the announcement. ${ }^{3}$ SaleGrowth is the value of sales in the financial year prior to announcement divided by sales in the previous year. $R O A$ is calculated as earnings before interest, depreciation, and amortization, divided by total book assets. ShareReturns is calculated for the twelve months prior to the 20 days before the announcement, equals to share price appreciation plus returns from dividends (assuming dividends are immediately reinvested), divided by the initial share price. ${ }^{4}$

The second set of control variables is CEO characteristics and corporate governance, to capture the amount of managerial entrenchment of the bidders and its association with CEO relative compensation. In our relative compensation experiments, we consider the following factors. BoardSize represents the number of directors on the board. InsiderRatio is the ratio of the number of executive directors on the board to the board size. CEO Duality is a dummy variable that takes the value of one if the manager also acts as the chairman, and zero otherwise. CEO Ownership is the ratio of ordinary shares owned by the CEO to the total number of ordinary shares outstanding, expressed in percentage. CEO Remuneration is a dummy variable that take the value of one if the CEO is a member of the remuneration committee. $C E O$ Nomination is dummy variable equal to one if the CEO is also a member of the nominating committee.

\footnotetext{
${ }^{3}$ The log transformation technique is conducted to lower the skewness of the raw data.

${ }^{4} \mathrm{ROA}$ and ShareReturns are winsorized at $5 \%$ each size to reduce the skewness of the raw data.
} 
IndustryDummies and YearDummies are also included in the estimation to control for the difference in CEO relative compensation among different industries over time.

High and low CEO relative compensation is defined by taking the residual from the regression. A positive residual will be categorised as high relative compensation, and a negative residual equivalent to low relative compensation. Relative compensation appears in this paper as both a dependent variable (in this section) and independent variable (in the following sections). However, we do not report and discuss the regression (1) result in this paper to focus on analysing relative compensation as an determinant factor to explain its consequences, which is an area of less empirical study (Finkelstein and Hambrick, 1996).

Table 1 reports the number and percentage of takeover deals announced by CEO with high and low relative compensation from 2000-2015. Table 1 evidences that the number of takeover deals undertaken by CEO with high relative pay is lower than number of deals conducted by CEO with low relative pay. 
Table 1: Summary of transaction - high relative compensation versus low relative compensation

\begin{tabular}{|c|c|c|c|c|c|}
\hline \multirow[b]{2}{*}{ Year } & \multirow[b]{2}{*}{ All } & \multicolumn{2}{|c|}{$\begin{array}{l}\text { High CEO } \\
\text { relative compensation }\end{array}$} & \multicolumn{2}{|c|}{$\begin{array}{l}\text { Low CEO } \\
\text { relative compensation }\end{array}$} \\
\hline & & $\begin{array}{l}\text { Number of } \\
\text { deals }\end{array}$ & Proportion & $\begin{array}{c}\text { Number of } \\
\text { deals }\end{array}$ & Proportion \\
\hline 2000 & 29 & 9 & $31.03 \%$ & 20 & $68.97 \%$ \\
\hline 2001 & 31 & 12 & $38.71 \%$ & 19 & $61.29 \%$ \\
\hline 2002 & 22 & 9 & $40.91 \%$ & 13 & $59.09 \%$ \\
\hline 2003 & 21 & 13 & $62 \%$ & 8 & $38 \%$ \\
\hline 2004 & 26 & 11 & $42.31 \%$ & 15 & $57.69 \%$ \\
\hline 2005 & 19 & 8 & $42.11 \%$ & 11 & $57.89 \%$ \\
\hline 2006 & 41 & 20 & $48.78 \%$ & 21 & $51.22 \%$ \\
\hline 2007 & 40 & 20 & $50 \%$ & 20 & $50 \%$ \\
\hline 2008 & 27 & 9 & $33.33 \%$ & 18 & $66.67 \%$ \\
\hline 2009 & 36 & 18 & $50 \%$ & 18 & $50 \% \mathrm{Po}$ \\
\hline 2010 & 29 & 10 & $34.48 \%$ & 19 & $65.52 \%$ \\
\hline 2011 & 23 & 11 & $47.83 \%$ & 12 & $52.17 \%$ \\
\hline 2012 & 23 & 7 & $30.43 \%$ & 16 & $69.57 \%$ \\
\hline 2013 & 27 & 9 & $33 \%$ & 18 & $67 \%$ \\
\hline 2014 & 15 & 8 & $53 \%$ & 7 & $47 \%$ \\
\hline 2015 & 13 & 6 & $46.15 \%$ & 7 & $53.85 \%$ \\
\hline Total & 422 & 180 & $42.65 \%$ & 242 & $57.35 \%$ \\
\hline \multicolumn{6}{|c|}{$\begin{array}{l}\text { This table shows the number and percentage of takeover deals by year and by level of CEO relative compensation, based on our } \\
\text { sample of } 422 \text { transactions conducted from } 2000-2015 \text {. Takeover deals are included in this sample if both targets and bidders } \\
\text { listed on the ASX; the offer price needs to be disclosed on either Connect4, Zephyr or company's statements; targets have daily } \\
\text { price data available on Sirca or DatAnalysis databases from two months prior to announcement to announcement date ; bidders } \\
\text { are not delisted within } 24 \text { months from announcement, have daily price data, valid monthly return index, monthly price to book } \\
\text { ratio, and monthly market capitalisation data on Sirca, DatAnalysis, and DataStream databases for } 24 \text { months after the } \\
\text { announcement month; bidder's CEO must be appointed before announcement date and remain in position in the announcement } \\
\text { year and the year prior to announcement year; bidder's CEO compensation and corporate governance data are available on } \\
\text { Connect } 4 \text { Boardroom, Sirca, and annual report. High and low relative compensation is defined by taking the residual from the } \\
\text { CEO relative regression. A positive residual will be categorised as high relative compensation, and a negative residual equivalent } \\
\text { to low relative compensation. }\end{array}$} \\
\hline
\end{tabular}

\subsection{Bid premium analysis}

Premiums are greatly sensitive to the decision makers, more particularly, premiums are heavily under the domination of top manager (Haspeslagh and Jemison, 1991). One focal point of this paper is on the role of CEO in paying for a deal in relation to his pay disparity. Following Hayward and Hambrick (1997), we estimate the following regression over the final sample: 


$$
\begin{aligned}
\text { BidPremium }= & \beta_{0}+\beta_{1} \text { CEORelComp }+\beta_{2} \text { RelativeSize }+\beta_{3} \text { DealValue }+ \\
& \beta_{4} \text { Diversify }+\beta_{5} \text { HostileBid }+\beta_{6} \text { CashPayment }+ \\
& \beta_{7} \text { SuccessfulDeal }+\beta_{8} \text { CompetingBid }+\beta_{9} \text { RevisedBid }+ \\
& {[\text { Industry Dummies }]+\varepsilon }
\end{aligned}
$$

The dependent variable in equation (2) is the acquisition premium (BidPremium) on an unaffected day prior to the announcement. Bid premium is the ratio of the offer price, minus the target share price 20 days prior to the announcement, divided by pretakeover share price, expressed in percentage. ${ }^{5}$

Independent variable CEORelComp is a dummy variable defined by sorting the residual from model (2), that equals to one with positive residual, and zero otherwise. Under the managerial theory a positive correlation between CEO relative compensation and takeover premium is expected. The efficient contracting theory emphasises that CEOs with high relative compensation should offer the "right" price for a deal. Thus, we do not make prediction on this relation.

RelativeSize is the ratio of target's total assets to bidder's total assets. ${ }^{6}$ Moeller et al. (2004) prove that managers larger of firms offer higher in acquisitions. The complication of incorporating large-size businesses can make potential synergies from the acquisitions more susceptible, and consequently lead to a lower premium. Thus, we predict a decrease effect of targets' size relative to bidders' size on the takeover premium.

DealValue is the dollar value of the deal. ${ }^{7}$ Roll (1986) and (Hayward and Hambrick, 1997) evidence higher bid premium for larger deals. In contrast, Alexandridis et al. (2013) detect significantly lower bid premium, arguing that the complexity of processing large deal associate with more uncertainty. As such, we make no prediction on the correlation between deal size and bid premium.

\footnotetext{
${ }^{5}$ We base on Connect 4 database to determine the takeover announced date. Offer price are extracted from Connect4 database and from companies' disclosure in some cases. Sirca and DatAnalysis are sources of share price for calculating acquisition premium.

${ }^{6}$ The original data was winsorized at $5 \%$ each size to reduce the skewness.

${ }^{7}$ The log transformation technique is conducted to lower the skewness of the raw data.
} 
Diversification is a dummy variable that equals to one if bidder and target are from different industry, and zero otherwise. ${ }^{8}$ It has been widely argued that whether or not the transaction is industry-related will influence the offer price (Jensen, 1986; Shleifer and Vishny, 2003). Diversification is used to measure the potential of the synergy and may link with higher risk. Thus a negative relation is predicted.

HostileTakeover is a dummy variable that takes the value of one if the bid attitude is hostile, and zero otherwise. ${ }^{9}$ Whether the bid attitude is hostile or friendly has been cited to result in the cost of acquisitions (Franks and Mayer, 1996; Moeller et al., 2004) It can be explained that a reject recommendation could increase higher the possibility of a price rise by the acquirers (Bugeja and Da Silva Rosa, 2010). However, previous investigation outcomes are diverse. While Franks and Mayer (1996) and Bugeja and Da Silva Rosa (2010) find a positive relation, Hayward and Hambrick (1997) and Henry (2005) fail to reveal a correlation between hostility and bid premium.

CompetingBid is a dummy variable that takes the value of one if there are at least two acquirers making an offer to a target, and takes the value of zero otherwise. Participating in the competition will induce bidders to pay more while they are also suffering from the target's resistance (Officer, 2003; Bhagat et al., 2005; Bugeja and Da Silva Rosa, 2010). However, an inverse relation may be the case if the first bidder overpaid on his offer, hence the potential competitors will be discouraging to enter the battle. Consequently, that deal will not contribute to the multiple bid sample which makes the premium of the single bidders to be higher (Eckbo, 2010)

SuccessfulDeal is a dummy variable that takes the value of one if the outcome of the offer is successful, and zero if a deal is unsuccessful or withdrawn. It is presumed that if bidders pay higher, there is a higher chance for the deal to be successful. In another case, there may be other factors that compensate for the price rising (Moeller et al., 2004)

\footnotetext{
${ }^{8}$ We use the Standards \& Poors Global Industry Classification Standard (GICS) to categorise every bidder and target industry. The ASX scheme was used before September 2002 which is then substituted by GICS. For observations occur before 2002, we base on the annual report of the transaction year and assign the firm to a new GICS code by using the ASX's remapping guidance.

9 The source of information is from Connec4 Takeover database where target board does not recommendation a takeover acceptance.
} 
CashPayment is a dummy variable that equals to one if the deal is financed exclusively in cash, and equals to zero otherwise. Previous studies suggest that the use of cash leads to higher takeover premiums (Wansley et al., 1983; Walkling, 1985; Lefanowicz et al., 2000; Schwert, 2000). The main possible reasons are cash finance provide a favourable condition in term of quicker time to process, the implication of undervaluation and the immediate capital gains tax exemption. This theory has been confirmed by Andrade et al. (2001), Fuller et al. (2002), Moeller et al. (2004) and Cai (2011).

BidRevision is a variable to present number of offer revision. A deal revision requires more skill than a single offer price. De et al. (1996) point out that offer revision may be the result of potential rivals, similar to the competing bidder factor. Moreover, the extra direct and indirect cost associated with a revised bid which makes the deal to be more expensive. Hence, a rise associated with bid revision is anticipated.

\subsection{Bidder Announcement Return Analysis}

\subsubsection{Calculating Cumulative-Abnormal-Returns}

This paper calculates three-day cumulative abnormal returns (CARs), adjusted against the All Ordinaries Index, around the announced date to measure the market's response to the takeover announcement. It is highly possible that a company engage in a takeover offer prior to the announced date that may bias the measurement of the market model Brown and Warner (1985). For this reason, we calculate the short-term abnormal returns using a modified market model to compare firms' returns with the equally weighted index return as follows.

The first step is estimating the CARs of companies' share returns three days around the announcement.

$$
A R_{i, t}=R_{i, t}-R_{m, t}
$$

where $A R_{i, t}$ is the excess return of bidder $i$ on day $t ; R_{i, t}$ is the return of bidder $i$ on day $t ; R_{m, t}$ is the market return estimated as the percentage change in All Ordinary Index on day $t$. We use the equally weighted index for this estimation because it has been demonstrated that using value weighted index does not considerably make the calculation better (Brown and Warner, 1985). 
In the next step, Cumulative Abnormal Returns (CARs) are computed as the sum of the Abnormal Returns $(A R i, t)$ over the three days around announced date as indicated by the following equation:

$$
C A R=\sum_{t=-1}^{t=+1} A R_{t}
$$

\subsubsection{Regression Model :}

We follow Hayward and Hambrick (1997) and Bouwman et al. (2009) to estimate the following model to account for the effect of CEO relative compensation on bidders' announcement returns.

$$
\begin{aligned}
\text { CAR }= & \beta_{0}+\beta_{1} \text { CEORelComp }+\beta_{2} \text { BidPremium }+\beta_{3} \text { RelativeSize } \\
& +\beta_{4} \text { DealValue }+\beta_{5} \text { Diversify }+\beta_{6} \text { HostileBid }+\beta_{7} \text { CashPayment }+ \\
& \beta_{8} \text { SuccessfulDeal }+\beta_{9} \text { CompetingBid }+\beta_{10} \text { RevisedBid }+ \\
& {[\text { Industry Dummies }]+\varepsilon }
\end{aligned}
$$

The dependent variable of interest, $C A R$, is the three days cumulative abnormal return around the announcement. Independent variable CEORelComp are dummy variables specified in 3.1. BidPremium is the ratio of the offer price, minus the target share price 20 days prior to the announcement, divided by pre-takeover share price, expressed in percentage. Other independent variables remain the same as in equation (2). Regarding the influence of CEO relative compensation on announcement return, a positive correlation is suggested by efficient contracting theory whereas if the managerial theory holds, a negative relation is expected.

\subsection{Bidder Long-term Return Analysis}

\subsubsection{Calculating Buy-and-Hold-Abnormal-Returns}

This paper analyses the bidder's excess returns which occur over 12 months and 24 months post announcement. Among a number of methods to calculate abnormal returns in the long window, Barber and Lyon (1997) prove that matching sample firms to control firms of similar size and book-to-market ratios reported the best result in all 
sample that they experiment. This methodology allows the alleviation of the new listing bias, the rebalancing bias, and the skewness bias.

Following Barber and Lyon (1997) and Lyon et al. (1999), we calculate 1-year and 2-years post-takeover buy-and-hold returns (BHRs) after controlling for survival, size and book to market ratio, for each acquiring firm in our sample that survives for the next 24 months post announcement. The matching procedure of a sample firm to a control firm of similar size and book-to-market ratio described bellow.

1. Identify all firms listed on the ASX that were not delisted and had share return index and book to market ratio data available over the $[0 ;+24]$ months after announcement.

2. Identify all firms with a market value of equity between $70 \%$ and $130 \%$ of the market value of equity of the sample firm at the beginning of the month prior to the announced month.

3. From the above set of firms, select the firm with a book-to-market ratio which is closest to that of the sample firm, at the beginning of the month prior to the announced month.

4. Calculate the buy-and-hold return over 12 months (or 24 months) for the control firm.

Step 2 to 4 in the above process are repeated for every firm in our sample.

A sample firm's buy-and-hold abnormal returns (BHARs) is then calculated by comparing its buy-and-hold returns (BHRs) to the BHRs of its control firm. Only firms with available data of return index and book to market ratio over the event window $[0,+24]$ are considered.

$$
B H A R_{i T}=R_{i T}-E\left(R_{i T}\right)
$$

where $B H A R_{\text {iт }}$ is the buy-and-hold abnormal returns for firm $\mathrm{i} ; R_{\text {iт }}$ is the monthly buy-and-hold return for firm i; $E\left(R_{\mathrm{iT}}\right)$ is the monthly buy-and-hold return of the control firm assigned to firm i over $\mathrm{T}$ months. $\mathrm{T}$ represents the 12 -month or 24 -month post announcement. 


\subsubsection{Regression Model}

After forming the control sample and coming up with the BHARs for each acquiring firm, we follow (Hayward and Hambrick, 1997) and Bouwman et al. (2009) to run the below regression on the abnormal performance of acquirers:

$$
\begin{aligned}
\text { BHAR }= & \beta_{0}+\beta_{1} \text { CEORelComp }+\beta_{2} \text { BidPremium }+\beta_{3} \text { RelativeSize }+ \\
& \beta_{4} \text { DealValue }+\beta_{5} \text { Diversify }+\beta_{6} \text { HostileBid }+\beta_{7} \text { CashPayment }+ \\
& \beta_{8} \text { SuccessfulDeal }+\beta_{9} \text { CompetingBid }+\beta_{10} \text { RevisedBid }+ \\
& {[\text { Industry Dummies }]+\varepsilon }
\end{aligned}
$$

The dependent variable, BHAR, is the one year and two years buy and hold abnormal returns of the acquiring firms. Independent variable CEORelComp is dummy variables specified in 3.1. Other independent variables remain the same as in equation (2).

According to managerial theory, it is hypothesized that managers are overconfident in their abilities or hold the optimistic view on the future of the synergy. Thus, the presence of managerial entrenchment should make bidders' long-term performance worse (Roll, 1986; Hayward and Hambrick, 1997; Malmendier and Tate, 2008; Croci et al., 2010; Bebchuk et al., 2011; Kolasinski and Li, 2013). However, if the efficient contracting hypothesis is prevalent, CEO relative compensation is the reflection of CEO's capacity and efforts, thus will benefit the long-term performance (Merhebi et al., 2006; Bugeja, Matolcsy, and Spiropoulos, 2017). 


\section{SAMPLE SELECTION}

Our sample is formed from three separate sources including Connect4, Zephyr and DatAnalysis databases. ${ }^{10}$ Our sample includes takeover deals between Australian bidders and targets over the 16 years period from 2000-2015. ${ }^{11}$

We require a takeover deal to fulfil the following conditions to be counted in the final sample:

- Both targets and bidders listed on the ASX.

- The offer price needs to be disclosed on either Connect4, Zephyr or company's statements. In stock payment and hybrid payment, the offer price is calculated by using the last trading day before the announcement of the deal.

- Targets have daily price data available on Sirca or DatAnalysis databases from two months prior to the announcement to the announcement date.

- Bidders are not delisted within 24 months from the announcement, have daily price data, valid monthly return index, monthly price to book ratio, and monthly market capitalisation data on Sirca, DatAnalysis, and DataStream databases for 24 months after the announcement month.

\footnotetext{
${ }^{10}$ To minimise the possibility of missing observations, we assemble and match information from the three sources. At the first step, we include all deals listing in each source to the population. The main issue within the initial list is the duplication of reports and an earlier offer of a transaction has been recorded as another deal. At the second step, we check all bid between a specific bidder and target to exclude any multiple records. We use annual reports, companies' announcements, and other information provided by in DatAnalysis database to verify any confusion. The data collection involved a significant amount of hand data gathering and manual tasks.

${ }^{11}$ We decide the sample period based on the data availability. Connect4 and DatAnalysis databases have data on mergers and acquisitions since 1997 while Zephyr database covers the period from 1999. It should be noted that Section 300A of the Corporations Law, inserted by the Company Law Review Act 1998, requires listed companies to disclosed directors and executive officers' compensation in the annual report, in more detail than previously required. Although the requirement was by law from the financial years ending on or after 1 July 1998, the availability of the information, both from companies' annual report and the databases is very limited, especially in the early years of implementing the requirement. Connect 4 and Sirca only provide data from the year 2000 and 2004 respectively, with a large number of missing observations. By using companies' annual report, announcement, website and public disclosures, we find very limited information regarding executive and director remuneration provided in all available sources. As such, our sample period starts from 2000. Where databases have the name of directors but no information on compensation is recorded, we manually obtain CEOs' compensation and corporate governance data from company annual reports. Regarding the cut off time, the last year in our sample is 2015 in order to have data to analyse the two years post announcement return of acquiring firms, at time of analysing.
} 
- Bidder's CEO must be appointed before announcement date and remain in position in the announcement year and the year prior to announcement year. Where acquiring firm does not have a CEO, the company's Chairman is counted.

In total, 422 takeover deals are finally selected after fulfilling our survival, data availability conditions and passing all eligible conditions. We require firms with complete relevant data to be kept. The number of observation was significantly reduced because of the availability of CEO compensation and corporate governance data.

\section{EMPIRICAL RESULT}

\subsection{Bid premium analysis}

\subsubsection{Univariate analysis}

The mean and median of takeover premium, grouped by high and low CEO relative compensation are presented in Table 2. We perform the parametric test and the nonparametric Mann-Whitney test to analyse the significance of the difference in both panels.

Table 2: Takeover premiums descriptive statistics

\begin{tabular}{lccccccc}
\hline & Obs & Mean(\%) & t-stat & p-value & Median(\%) & Z-stat & p-value \\
\hline $\begin{array}{c}\text { All transactions } \\
\text { Low relative } \\
\text { compensation }\end{array}$ & 422 & 24.70 & & & 21.60 & & \\
$\begin{array}{c}\text { High relative } \\
\text { compensation } \\
\text { Difference test }\end{array}$ & 180 & 26.44 & & & 19.94 & & \\
& & -1.1010 & 0.1358 & & -1.520 & 0.1286 \\
\hline
\end{tabular}

This table shows the summary statistics of takeover premium of our sample of 422 transactions announced from 2000 to 2015 between listed targets and bidders that satisfied the sample selection requirements. Takeover premiums are calculated using target share price 20 days prior to the announcement, grouped by CEO with high a low relative compensation. High and low relative compensation is defined based on the residual of CEO relative compensation equation.

Table 2 contains descriptive statistics for the sub-analysis partitioned by high and low CEO relative compensation, as classified in Section 3.1. It can be seen that over the 16 years period from 2000 to 2015, the mean and the median of takeover premium of the total sample is approximately $24.7 \%$ and $21.6 \%$ respectively. Takeover premium of deals undertaken by CEO with high relative pay are $26.44 \%$ on average 
while a premium of $23.41 \%$ is recorded for deals initiated by CEO with low relative compensation. The median value of two subsamples are $26.19 \%$ and $19.94 \%$ respectively. However, the mean and the median difference are not statistically significant. Our findings are somewhat similar to the view of efficient contracting theory which does not focus on how high or low offer that competent CEO make, but how appropriate it is. The following sections will confirm if this theory's underlying reasons applied in the Australian context.

\subsubsection{Multivariate analysis}

The purpose of this section is to control for variables other than CEO relative compensation that may weight up or down the takeover premium. Table 3 presents regression models to analyse the takeover premium. Model (1) is the test of the influence of high and low CEO relative compensation on takeover premium after controlling for the relative size and deal value. Model (2) adds deal characteristic variables.

As indicated in Table 3, the insignificant increase of takeover premium caused by CEO relative compensation interestingly confirms our univariate analysis that although being paid relatively higher than their peers, there is not enough evidence to conclude that CEOs aggressively escalate the offer. This result is of the contradiction to the view of managerial hypothesis followers, who contend that managers tend to reflect their arrogance and self-interests into organisation's strategies, including setting the price for a takeover deal (Hayward and Hambrick, 1997). These managers usually search for a market timing that contains overvaluation or undervaluation stocks, being optimistic about their estimation, hence upsurge the bid premium (Roll, 1986; Scharfstein and Stein, 1990; Shleifer and Vishny, 2003; Rhodes-Kropf and Viswanathan, 2004; Dong et al., 2006). Given the consistent result with the univariate analysis, Model (1) and Model (2) provide additional backing for efficient contracting theory that individual trait is not a factor of takeover premium, and higher compensation should associate with CEO's knowledge and skills that prevent managers to process an overpriced transaction (Lazear and Rosen, 1981; Jovanovic and Rousseau, 2002; Harford, 2005; Chang et al., 2010). 
Table 3: Regression on Bid Premium

\begin{tabular}{|c|c|c|}
\hline & (1) & (2) \\
\hline \multirow[t]{2}{*}{ RelComp } & 0.0419 & 0.0447 \\
\hline & $(1.54)$ & $(1.63)$ \\
\hline \multirow[t]{2}{*}{ RelativeSize } & $-0.0520 * * *$ & $-0.0514^{* * * *}$ \\
\hline & $(-3.50)$ & $(-3.41)$ \\
\hline \multirow[t]{2}{*}{ DealValue } & 0.00274 & 0.00116 \\
\hline & $(0.41)$ & $(0.17)$ \\
\hline \multirow[t]{2}{*}{ Diversify } & & $-0.0639^{*}$ \\
\hline & & $(-1.91)$ \\
\hline \multirow[t]{2}{*}{ HostileBid } & & -0.0135 \\
\hline & & $(-0.36)$ \\
\hline \multirow[t]{2}{*}{ StockPayment } & & -0.00664 \\
\hline & & $(-0.23)$ \\
\hline \multirow[t]{2}{*}{ SuccessfulDeal } & & -0.0165 \\
\hline & & $(-0.46)$ \\
\hline \multirow[t]{2}{*}{ CompetingBid } & & $-0.0731^{* *}$ \\
\hline & & $(-1.97)$ \\
\hline \multirow[t]{2}{*}{ RevisedBid } & & 0.0329 \\
\hline & & $(1.30)$ \\
\hline Industry Fixed Effects & Yes & Yes \\
\hline$\overline{R^{2}}$ & $6.6 \%$ & $8.4 \%$ \\
\hline$N$ & 422 & 422 \\
\hline
\end{tabular}

This table shows the results of OLS regression of takeover premium on CEO relative compensation, firm size and deal characteristics. The sample consists of 422 transactions announced from 2000 to 2015 between listed targets and bidders that satisfied the sample selection requirements. Takeover premiums are calculated using target share price 20 days prior to the announcement. Model (1) is the test of the influence of high and low CEO relative compensation on takeover premium after controlling for the relative size and deal characteristics. Model (2) add the industry fixed effect. High and low relative compensation is defined based on the residual of CEO relative compensation equation. Bold figures indicate the difference are significant at the level of $10 \%$ or better.

$\mathrm{t}$ statistics in parentheses

$* \mathrm{p}<0.1, * * \mathrm{p}<0.05, * * * \mathrm{p}<0.01$

Regarding the control variables, relative size (RelativeSize), measured as is the ratio of target's total book value of assets and that of the bidder, negatively correlated to the expensiveness of the deal across three models. The information asymmetry increase with size and greater risks are cited for this negative correlation. This finding is opposite to the view of the managerial theory that CEOs have the incentive to increase firms' size as part of the empire building at the expense of shareholders' interests (Morck et al., 1990). The coefficient of Diversify, which is the measurement of industry relatedness between bidder and target is negative, significant and predicted. It may be the case that an ordinal CEO may not efficient in evaluating the target and may pay more for the transaction. In another case, manager may want to expand the 
business for the purpose of empire building or other self-incentives. However, we find supportive evidence for the efficient contracting hypothesis that CEO is not willing to pay more in a diversified transaction. The presence of competing bidders (CompetingBid) also inversely correlated to bid premium and consistent with Bugeja, Matolcsy, Mehdi, et al. (2017) finding. Although it has been argued that the rival threat may promote an expensive takeover, the negative relation between competing bidders and bid premium found in this research favour the position that an "already" high offer will prevent competitor to make an offer and that deal will not be recorded in the competing bidder sample. This result is in sharp contrast with the US market revealed by Hayward and Hambrick (1997). Another possible explanation is skilled CEOs base on the fundamental factors to pay for a deal base thus the rival threat does not lead to a higher offer.

\subsection{Bidder's performance analysis}

\subsubsection{Univariate analysis}

Table 4 illustrates the result of the significance test of CARs, 1-year BHARs and 2-years BHARs around the announced date, categorised by high and low CEO relative compensation. Overall, deals conducted by CEO with a high relative pay to the total compensation of the board received an immediate unfavourable response from the market but lucrative to the acquirer in the long-term.

Panel A compares abnormal returns around takeover announcement gained by CEO with high and low relative remuneration. Overall, positive announcement returns of all takeover deals are observed which is in accord with recent Australian study of Simmonds (2004), Porter and Singh (2010) and (Shams et al., 2013). However, takeover deals taken placed by CEO with high relative pay has been suffered $-0.72 \%$ cumulative abnormal returns three days surrounding takeover announcement, which is much lower than that of CEO with low relative compensation who own $0.78 \%$ on average. The difference is significant at $1 \%$ level. The median value follows the same patent and statistically significant. These results are consistent with the findings of Bebchuk et al. (2011) who equalize the result to the agency problem. However, we conjecture that although the immediate market reaction seems conspicuous to deal 
announced by CEO with high relative compensation, we yet to link our evidence to a theory until long-term performance analysis is conducted.

Table 4: Bidders' performance descriptive statistics

\begin{tabular}{|c|c|c|c|c|c|c|c|}
\hline & Obs & Mean & t-stat & p-value & median & z-stat & p-value \\
\hline \multicolumn{8}{|l|}{ Panel A: CAR } \\
\hline $\begin{array}{l}\text { All transactions } \\
\text { Low relative } \\
\text { compensation } \\
\text { High relative } \\
\text { compensation } \\
\text { Difference test }\end{array}$ & $\begin{array}{l}422 \\
242\end{array}$ & $\begin{array}{l}0.1391 \\
0.7813 \\
-0.7243\end{array}$ & 2.4893 & 0.9934 & $\begin{array}{l}-0.4156 \\
0.2200 \\
-0.8124\end{array}$ & 2.3500 & 0.0188 \\
\hline \multicolumn{8}{|c|}{ Panel B: 1-year BHAR } \\
\hline $\begin{array}{l}\text { All transactions } \\
\text { Low relative } \\
\text { compensation } \\
\text { High relative } \\
\text { compensation } \\
\text { Difference test }\end{array}$ & $\begin{array}{l}422 \\
242\end{array}$ & $\begin{array}{l}-7.4031 \\
-11.7724 \\
-1.5288\end{array}$ & -1.5915 & 0.0561 & $\begin{array}{l}-3.7781 \\
-8.5344 \\
0.3219\end{array}$ & -1.721 & 0.0853 \\
\hline \multicolumn{8}{|c|}{ Panel C: 2 year BHAR } \\
\hline $\begin{array}{l}\text { All transactions } \\
\text { Low relative } \\
\text { compensation } \\
\text { High relative } \\
\text { compensation } \\
\text { Difference test }\end{array}$ & $\begin{array}{l}422 \\
242\end{array}$ & $\begin{array}{l}-6.2584 \\
-6.7963 \\
-5.5351\end{array}$ & -0.1443 & 0.4427 & $\begin{array}{l}-2.9004 \\
-4.3574 \\
3.6550\end{array}$ & -0.472 & 0.6371 \\
\hline $\begin{array}{l}\text { This table shows the } \\
\text { announced from } 200 \\
\text { presents a compariso } \\
\text { Panel B and Panel C } \\
2 \text { years respectively. } \\
\text { equation. Bold figur } \\
\text { t statistics in parenth } \\
* \text { p }<0.1, * * p<0.0\end{array}$ & $\begin{array}{l}\text { a comp } \\
\text { low } r \\
\text { e the di } \\
0.01\end{array}$ & $\begin{array}{l}\text { of CAR }(-1 ; 1) \\
\text { listed targets a } \\
\text { edian value of } \\
\text { son of the me } \\
\text { ive compensa } \\
\text { ence are signi }\end{array}$ & $\begin{array}{l}\text {-year BHA } \\
\text { d bidders th } \\
\text { amulative al } \\
\text { and median } \\
\text { n is definec } \\
\text { cant at the le }\end{array}$ & $\begin{array}{l}\text { and 2-year } \\
\text { satisfied the } \\
\text { ormal return } \\
\text { alue of buy } \\
\text { ased on the } \\
\text { el of } 10 \% \text { or }\end{array}$ & $\begin{array}{l}\text { AAR of our } \\
\text { ample select } \\
\text { three days s } \\
\text { a hold abnc } \\
\text { esidual of C } \\
\text { etter. }\end{array}$ & $\begin{array}{l}\text { mple of } 422 \\
\text { n requirem } \\
\text { rounding an } \\
\text { mal returns } \\
\text { O relative c }\end{array}$ & $\begin{array}{l}\text { ransactions } \\
\text { ts. Panel A } \\
\text { ouncement. } \\
1 \text { year and } \\
\text { mpensation }\end{array}$ \\
\hline
\end{tabular}

Panel B and Panel C report that takeovers are value-decreasing in the long term, which is in agreement prior research of Chan and Emanuel (2011) and Duong and Izan (2012) on Australian bidder long-term performance. Closer inspection of Panel B and Panel $\mathrm{C}$ shows that the long-term influence of high and low CEO relative compensation is in a different direction compared with the short-term returns. In one year, takeover deals conducted by CEO with high relative compensation suffering the milder loss of $-1.53 \%$ compared to a substantial loss of $-11.77 \%$ for deals initiated by CEO with low relative compensation. The difference is significant in term of the average value and the centre value at 5\% level. In two years, the same pattern is revealed in both one year and two buy and hold abnormal returns. However the 
difference becomes marginal and insignificant. Overall, we reveal signals of market correction against the bidder's performance surrounding announcement. This outcome is contrary to the evidence from the US market, observed by Hayward and Hambrick (1997).

\subsubsection{Multivariate analysis}

Literature has suggested a number of the determinants of acquirers' abnormal returns. In this section, we estimate the effect of those factors which result in the market response to the takeover deals in short-term and long-term. Three models are considered. Model (1) inspects the alteration effects of high and low CEO relative pay on acquirer's announcement returns. Model (2) targets at how do high and low CEO relative compensation drive bidder's performance in 1-year post announcement. Model (3) examines how do high and low CEO relative compensation drive bidder's performance in 2-year windows. With reference to the literature, control variables included in the three models are bid premium, the relative size of target and bidder, deal size, diversify, hostile bid, stock payment, successful deal, competing bidders and number of the revised offer.

It can be seen in Model (1) that when high and low CEO relative compensation are stimulated with the bidders' cumulative abnormal returns three days surrounding announcement, after controlling for the above factors, a significant increase was detected. Comparing with prior research, Hayward and Hambrick (1997) investigate CEO relative compensation and link this ratio to CEO overconfidence. However, they do not regress this variable against acquirer's immediate returns. Masulis et al. (2007) do not look into CEO compensation but they find that entrenchment results in poorer perfomance. Croci et al. (2010) are interested the term CEO overconfidence, but they use different measurement related to stock options. They find a negative impact of overconfident $\mathrm{CEO}$ on announcement return, which has the same sign with our findings.

Table 5: Regression on CAR $(-1 ; 1)$, 1-year BHAR and 2-year BHAR 


\begin{tabular}{|c|c|c|c|}
\hline & $\begin{array}{c}(1) \\
\text { CAR }\end{array}$ & $\begin{array}{c}(2) \\
\text { 1-year BHAR }\end{array}$ & $\begin{array}{c}\text { (3) } \\
\text { 2-year BHAR }\end{array}$ \\
\hline RelComp & $\begin{array}{l}-1.257^{* *} \\
(-2.08)\end{array}$ & $\begin{array}{l}0.106 * \\
(1.65)\end{array}$ & $\begin{array}{c}0.0062 \\
(0.07)\end{array}$ \\
\hline RelativeSize & $\begin{array}{l}0.353 \\
(1.04)\end{array}$ & $\begin{array}{c}0.0319 \\
(0.88)\end{array}$ & $\begin{array}{c}0.0717 \\
(1.43)\end{array}$ \\
\hline BidPremium & $\begin{array}{l}-1.003 \\
(-0.92)\end{array}$ & $\begin{array}{l}0.100 \\
(0.86)\end{array}$ & $\begin{array}{l}0.216 \\
(1.35)\end{array}$ \\
\hline DealValue & $\begin{array}{c}-0.422^{* * * *} \\
(-2.78)\end{array}$ & $\begin{array}{c}0.0354^{* *} \\
(2.20)\end{array}$ & $\begin{array}{c}0.0152 \\
(0.68)\end{array}$ \\
\hline Diversify & $\begin{array}{c}0.0762 \\
(0.10)\end{array}$ & $\begin{array}{l}-0.0500 \\
(-0.64)\end{array}$ & $\begin{array}{l}-0.261^{* *} \\
(-2.40)\end{array}$ \\
\hline HostileBid & $\begin{array}{l}-0.341 \\
(-0.42)\end{array}$ & $\begin{array}{c}0.178^{* *} \\
(2.04)\end{array}$ & $\begin{array}{l}0.101 \\
(0.84)\end{array}$ \\
\hline CashPayment & $\begin{array}{l}-0.334 \\
(-0.49)\end{array}$ & $\begin{array}{c}0.184^{* *} \\
(2.56)\end{array}$ & $\begin{array}{c}0.0836 \\
(0.84)\end{array}$ \\
\hline SuccessfulDeal & $\begin{array}{l}1.278 \\
(1.60)\end{array}$ & $\begin{array}{c}0.248^{* * *} \\
(2.92)\end{array}$ & $\begin{array}{c}0.0125 \\
(0.11)\end{array}$ \\
\hline CompetingBid & $\begin{array}{c}1.794^{* *} \\
(2.19)\end{array}$ & $\begin{array}{c}0.226^{* * * *} \\
(2.60)\end{array}$ & $\begin{array}{c}0.0707 \\
(0.59)\end{array}$ \\
\hline RevisedBid & $\begin{array}{l}0.538 \\
(0.97)\end{array}$ & $\begin{array}{c}-0.0658 \\
(-1.11)\end{array}$ & $\begin{array}{c}0.0387 \\
(0.47)\end{array}$ \\
\hline Industry Fixed Effects & Yes & Yes & Yes \\
\hline$R^{2}$ & $9.7 \%$ & $9.0 \%$ & $5.3 \%$ \\
\hline$N$ & 422 & 422 & 422 \\
\hline
\end{tabular}

This table shows the results of OLS regression of CAR(-1;1), 1-year BHAR and 2-year BHAR onCEO relative compensation, firm size and deal characteristics. The sample consists of 422 transactions announced from 2000 to 2015 between listed targets and bidders that satisfied the sample selection requirements. Model 1 presents the regression of cumulative abnormal returns three days surrounding announcement. Model 2 and Model 3 present the regression on of buy and hold abnormal returns in 1 year and 2 years respectively. CEO relative compensation, defined based on the residual of CEO relative compensation equation. Bold figures indicate the difference are significant at the level of $10 \%$ or better.

$t$ statistics in parentheses

${ }^{*} p<0.1,{ }^{* *} p<0.05,{ }^{* * *} p<0.01$

Of the driving force of other control variables on announcement returns, the coefficient of DealValue is negative and statistically significant, indicating that larger deals reduce bidder's cumulative abnormal returns surrounding announcement. This result is consistent with acquirer's short-term return literature which suggests that larger deal associated with higher risk and responded negatively by the market around the announced date. This finding is similar to the study of Alexandridis et al. (2013) who documented that investors regard larger deal with more uncertainty, and ultimately deteriorates bidders' returns in short-term. CompetingBid is positive and significant in Model (1) and Model (2), indicating that the presence of rivals increases returns of the winner from announcement until a year later. Under the efficient contracting theory, CEO relative compensation is a proxy for shareholders' view on 
CEO ability and reputation. A high relative pay motivates CEO to take value enhancing investment. High relative pay also gives signal that manager has sufficient skills and have more information than the competitor about the long-term prospect of the deal (Stein, 1988, 1989; Almazan and Suarez, 2003; Ju et al., 2014). Thus, the winner of a deal with competing bidder is rewarded and contribute positively to bidder's gain.

Regarding the impact of CEO relative compensation on long-term buy and hold abnormal returns, the correlation is positive, significant at $10 \%$ level in 1 year and insignificant in 2-year returns. These results corroborate with our earlier observations that although experiencing lower returns surrounding takeover announcement, CEO with high relative compensation has strategy that generates better result than the decision of CEO with low relative compensation. This outcome is contrary to that of the US market where CEO relative compensation negatively correlated to the bidders' abnormal returns in long-term (Hayward and Hambrick, 1997).

Turning now to the determinacies of control variables on long-term performance, the increase in the deal value (DealValue) give rise to acquirers' BHAR in long-term post takeovers. The correlation is significant at 5\% level in one-year BHARs and becomes insignificant in two years performance. These results are in line with those obtained by Asquith et al. (1983), Eckbo et al. (1990) and Moeller et al. (2005). It should be noted that deal value has a negative correlation with short-term returns. This discrepancy could be clarified that investors are vulnerable to large deal surrounding announcement. However market will make a correction to reward the sizable deal that usually being evaluated carefully by the bidder, hence stimulates the performance in long-term. The coefficient of Diversification is negative and significant at 5\% level in two years post announcement. This finding was also reported by Bhagat et al. (2005), explained that market recognizes diversification as an indicator of agency problems and management complexity, whereas transaction happens within industry signpost managerial restraint, capability and potential synergy. Successful deal (SuccessfulDeal) unlocks the synergy, results in the combination of assets and resources, the potential benefits of the economies of scale and the enhancement of product efficiency. Our findings are consistent with ones observed by Bradley et al. (1988) and Duong and Izan (2012) in the Australian market. Similar to the short-term 
analysis, the coefficient of CompetingBid are positive, significant. It is worth to note that the above variables represent the skills and efforts required from CEOs in completing the deals. In Model (2), the coefficients of all those variables are positive, indicating that competent CEOs have successfully used their abilities to outperform the market. BidPremium is not a significant determinant of bidder performance in both short-term and long-term performance, which is a confirmation of Duong and Izan (2012) observation in the Australian market.

In general, our findings on the correlation of CEO relative compensation with acquirers' performance is in contrary to previous research in the US that found evidence of CEO hubris and entrenchment that deteriorate firm's future prospect. Our analysis infers to the efficiency of contracting. In particular, based on our sample, we support that CEO is paid by their capacity and competence. Although may not be reacted positively by the market in the short-term, CEOs with high relative compensation have sufficient knowledge and skills to outperform the market to bring long-term benefit to their organisations. The discrepancy between the Australian and the US market could be attributed to the difference in the regulatory and corporate governance framework in the two countries. Australia has a number of provisions controlling for executive pay, including the Australian Corporations Act, the ASX Corporate Governance Council corporate governance principles and recommendations and the ASX Listing rules. Of note is that, these regulations focus on enhancing the link between firm's performance and directors' pay (Schoenemann, 2006). Moreover, Hill et al. (2011) posit that Australian shareholders impose noticeably sturdier rights in corporate governance including the nomination and remuneration of directors. Thereby, the regulatory framework could be a supporting factor for firms that pay higher CEO relative compensation to attract outstandingly capable managers, and ultimately add value to the organisation.

\subsection{Robustness}

We ran a number of robustness test. Firstly, we rank high and low relative compensation based on the industry average. Each CEO is identified to be paid a high relative compensation if the ratio is above the industry average. Alternatively, CEO is classified to be paid a low relative compensation if the ratio is higher than the industry average. Secondly, we calculate bid premium based on 30 days and 60 days target 
share price to replace for the bid premium 20 days prior to the announcement. Thirdly, we measure the short term returns by computing cumulative abnormal returns 5 days and 11 days around announcement date. The results of the above tests are similar to the main analysis.

\section{CONCLUSION}

The present paper was designed to determine the effect of CEO relative compensation on takeover premium and bidders' performance. Our investigation confirmed that CEO relative compensation makes insignificant difference on takeover premium. In other words, we do not find sufficient evidence that CEO with high relative compensation pays higher price than CEO with low relative compensation. Interestingly, although experiencing less welcoming market's response surrounding announcement, takeover conducted by CEO with high relative compensation is rewarded in the long term. In general, findings from our CEO relative compensation analysis are contrary to studies in other markets which associate high CEO relative compensation with managerial entrenchment. Instead, we evidence the explanatory power of the efficient contracting hypothesis for the influence of CEO relative compensation on the takeover consequences. These results are likely to be related to the differences in the regulatory framework and corporate governance practices in Australia in comparison to other markets. 


\section{BIBLIOGRAPHY}

Alexandridis, G., Fuller, K. P., Terhaar, L., \& Travlos, N. G. (2013). Deal size, acquisition premia and shareholder gains. Journal of Corporate Finance, 20, 1-13. doi: 10.1016/j.jcorpfin.2012.10.006

Almazan, A., \& Suarez, J. (2003). Entrenchment and severance pay in optimal governance structures. The Journal of Finance, 58(2), 519-547.

Andrade, G., Mitchell, M., \& Stafford, E. (2001). New Evidence and Perspectives on Mergers. Journal of Economic Perspectives, 15(2), 103-120.

Asquith, P., Bruner, R. F., \& Mullins Jr, D. W. (1983). The gains to bidding firms from merger. Journal of Financial Economics, 11(1-4), 121-139.

Barber, B. M., \& Lyon, J. D. (1997). Detecting long- run abnormal stock returns: The empirical power and specification of test statistics. Journal of Financial Economics, 43(3), 341-372. doi: 10.1016/S0304-405X(96)00890-2

Bebchuk, L. A., Cremers, K. J. M., \& Peyer, U. C. (2011). The CEO pay slice. Journal of Financial Economics, 102(1), 199-221. doi: 10.1016/j.jfineco.2011.05.006

Bebchuk, L. A., \& Fried, J. M. (2003). Executive Compensation as an Agency Problem. Journal of Economic Perspectives, 17(3), 71-92. doi: $10.1257 / 089533003769204362$

Bhagat, S., Dong, M., Hirshleifer, D., \& Noah, R. (2005). Do tender offers create value? New methods and evidence. Journal of Financial Economics, 76(1), 360. doi: https://doi.org/10.1016/j.jfineco.2004.05.002

Bishop, S., Dodd, P., \& Officer, R. R. (1987). Australian Takeovers: The Evidence. Policy Monographs; No 12. The centre for independent study limited.

Borokhovich, K. A., Brunarski, K. R., \& Parrino, R. (1997). CEO Contracting and Antitakeover Amendments. Journal of Finance, 52(4), 1495-1517. doi: 10.1111/j.1540-6261.1997.tb01118.x

Bouwman, C. H. S., Fuller, K., \& Nain, A. S. (2009). Market Valuation and Acquisition Quality: Empirical Evidence. The Review of Financial Studies, 22(2), 633-679.

Bradley, M., Desai, A., \& Kim, E. H. (1988). Synergistic gains from corporate acquisitions and their division between the stockholders of target and acquiring firms. Journal of Financial Economics, 21(1), 3-40. doi: 10.1016/0304405X(88)90030-X

Brown, S. J., \& Warner, J. B. (1985). Using daily stock returns: The case of event studies. Journal of Financial Economics, 14(1), 3-31. doi: 10.1016/0304405X(85)90042-X

Bugeja, M., \& Da Silva Rosa, R. (2010). Capital gains taxation and shareholder wealth in takeovers. Accounting \&amp; Finance, 50(2), 241-262. doi: 10.1111/j.1467629X.2009.00334.x

Bugeja, M., Da Silva Rosa, R., Duong, L., \& Izan, H. Y. (2012). CEO Compensation from M\&As in Australia. Journal of Business Finance \& Accounting, 39(910), 1298-1329. doi: 10.1111/j.1468-5957.2012.02299.x

Bugeja, M., da Silva Rosa, R., Izan, H., \& Ngan, S. (2016). To scheme or bid? Choice of takeover method and impact on premium. Australian Journal of Management, 41(2), 212-243. 
Bugeja, M., \& Loyeung, A. (2017). Accounting for business combinations and takeover premiums: Pre-and post-IFRS. Australian Journal of Management, 42(2), 183-204.

Bugeja, M., Matolcsy, Z., Mehdi, W., \& Spiropoulos, H. (2017). Is non-executive directors' pay or industry expertise related to takeover premiums, abnormal returns and offer price revisions? Australian Journal of Management, 42(3), 355-375. doi: 10.1177/0312896216643566

Bugeja, M., Matolcsy, Z., \& Spiropoulos, H. (2017). The CEO pay slice: Managerial power or efficient contracting? Some indirect evidence. Journal of Contemporary Accounting \&amp; Economics, 13(1), 69-87. doi: 10.1016/j.jcae.2017.01.003

Cai, Z. (2011). Shade delayed flowering and decreased photosynthesis, growth and yield of Sacha Inchi (Plukenetia volubilis) plants. Industrial Crops and Products, 34(1), 1235-1237.

Chalmers, K., Koh, P.-S., \& Stapledon, G. (2006). The determinants of CEO compensation: Rent extraction or labour demand? The British Accounting Review, 38(3), 259-275. doi: 10.1016/j.bar.2006.01.003

Chan, W., \& Emanuel, D. (2011). Board governance and acquirers' returns: A study of Australian acquisitions. Aust. J. Manag., 36(2), 174-199. doi: 10.1177/0312896210394499

Chang, Y. Y., Dasgupta, S., \& Hilary, G. (2010). CEO Ability, Pay, and Firm Performance. Management Science, 56(10), 1633-1652. doi: 10.1287/mnsc. 1100.1205

Christopher, B. M., \& Zicheng, O. (2008). Acquisition actions in Australia: a test of acquisitions theory. International Journal of Managerial Finance, 4(3), 220231. doi: $10.1108 / 17439130810878802$

Core, J. E., Holthausen, R. W., \& Larcker, D. F. (1999). Corporate governance, chief executive officer compensation, and firm performance Journal of Financial Economics, 51(3), 371-406. doi: 10.1016/S0304-405X(98)00058-0

Croci, E., Petmezas, D., \& Vagenas-Nanos, E. (2010). Managerial Overconfidence in High and Low Valuation Markets and Gains to Acquisitions. International Review of Financial Analysis, 19(5), 368-378. doi: 10.1016/j.irfa.2010.06.003

Cropanzano, R., Byrne, Z. S., Bobocel, D. R., \& Rupp, D. E. (2001). Moral Virtues, Fairness Heuristics, Social Entities, and Other Denizens of Organizational Justice. Journal of Vocational Behavior, 58(2), 164-209. doi: https://doi.org/10.1006/jvbe.2001.1791

Cyert, R. M., \& March, J. G. (1963). A behavioral theory of the firm. Englewood Cliffs, NJ, 2, 169-187.

Da Silva Rosa, R., \& Walter, T. (2004). Australian mergers and acquisitions since the 1980s : what do we know and what remains to be done? Australian Journal of Management(29), i-xiii.

De, S., Fedenia, M., \& Triantis, A. J. (1996). Effects of competition on bidder returns. Journal of Corporate Finance, 2(3), 261-282. doi: 10.1016/09291199(95)00011-9

Dong, M., Hirshleifer, D., Richardson, S., \& Teoh, S. (2006). Does Investor Misvaluation Drive the Takeover Market? The Journal of Finance, 61(2), 725762.

Duong, L., \& Izan, I. H. Y. (2012). Consequences of Riding Takeover Waves: Australian Evidence. International Review of Finance, 12(4), 399-434. 
Eckbo, B. E. (2010). Takeover Activity, Valuation Estimates and Merger Gains: Modern Empirical Developments (Vol. 1): Academic Press.

Eckbo, B. E., Giammarino, R. M., \& Heinkel, R. L. (1990). Asymmetric information and the medium of exchange in takeovers: Theory and tests. The Review of Financial Studies, 3(4), 651-675.

Fernandes, N., Ferreira, M. A., Matos, P., \& Murphy, K. J. (2013). Are U.S. CEOs Paid More? New International Evidence. The Review of Financial Studies, 26(2), 323-367. doi: 10.1093/rfs/hhs 122

Finkelstein, S., \& Hambrick, D. (1996). Strategic leadership : top executives and their effects on organizations Minneapolis/St. Paul: Minneapolis/St. Paul : West Pub. Co.

Fong, E. A. (2010). Relative CEO Underpayment and CEO Behaviour Towards R\&amp;D Spending. Journal of Management Studies, 47(6), 1095-1122. doi: 10.1111/j.1467-6486.2009.00861.x

Frank, R. H. (1985). Choosing the right pond: human behavior and the quest for status / Robert H. Frank. New York: New York: Oxford University Press.

Franks, J., \& Mayer, C. (1996). Hostile takeovers and the correction of managerial failure. Journal of Financial Economics, 40(1), 163-181. doi: https://doi.org/10.1016/0304-405X(95)00840-B

Fuller, K., Netter, J., \& Stegemoller, M. (2002). What do returns to acquiring firms tell us? Evidence from firms that make many acquisitions. The Journal of Finance, 57(4), 1763-1793.

Grinstein, Y., \& Hribar, P. (2004). CEO compensation and incentives: Evidence from M\&A bonuses. J. Financ. Econ., 73(1), 119-143. doi: 10.1016/j.jfineco.2003.06.002

Hambrick, D. C., \& Cannella, A. A. (1993). Relative standing: A framework for understanding departures of acquired executives. Academy of Management journal, 36(4), 733-762.

Harford, J. (2005). What Drives Merger Waves? Journal of Financial Economics, 77(3), 529-560. doi: 10.1016/j.jfineco.2004.05.004

Hart, O. D., \& Holmstrom, B. (1986). The theory of contracts.

Haspeslagh, P. C., \& Jemison, D. B. (1991). Managing acquisitions: Creating value through corporate renewal (Vol. 416): Free Press New York.

Hayward, M. L. A., \& Hambrick, D. C. (1997). Explaining the Premiums Paid for Large Acquisitions: Evidence of CEO Hubris. Administrative Science Ouarterly, 42(1), 103-127.

Henry, D. (2005). Directors' Recommendations in Takeovers: An Agency and Governance Analysis. Journal of Business Finance \& Accounting, 32(1/2), 129-159. doi: 10.1111/j.0306-686X.2005.00590.x

Henry, D. (2008). Corporate Governance Structure and the Valuation of Australian Firms: Is There Value in Ticking the Boxes? Journal of Business Finance \& Accounting, 35(7/8), 912-942. doi: 10.1111/j.1468-5957.2008.02100.x

Hill, J. G., Masulis, R. W., \& Thomas, R. S. (2011). Comparing CEO employment contract provisions: Differences between Australia and the United States. Vanderbilt Law Review, 64(2), 559-608. doi: 10.2139/ssrn.1664615

Hodne, N., Murphy, S., Ottenbacher, M., \& Ruggles, T. (2013). Australia and the United States: A Comparison and Contrast of Corporate Governance. Drake Management Review, 3(1). 
Izan, H. Y., Sidhu, B., \& Taylor, S. (1998). Does CEO Pay Reflect Performance? Some Australian Evidence. Corporate Governance: An International Review, 6(1), 39-47. doi: 10.1111/1467-8683.00078

Jensen, M. C. (1986). Agency Costs of Free Cash Flow, Corporate Finance, and Takeovers. American Economic Review, 76(2), 323.

Jensen, M. C., \& Meckling, W. H. (1976). Theory of the firm: Managerial behavior, agency costs and ownership structure. Journal of Financial Economics, 3(4), 305-360. doi: 10.1016/0304-405X(76)90026-X

Jovanovic, B., \& Rousseau, P. L. (2002). The Q-theory of Mergers (Vol. 92, pp. 198204).

Ju, N., Leland, H., \& Senbet, L. W. (2014). Options, option repricing in managerial compensation: Their effects on corporate investment risk. Journal of Corporate Finance, 29, 628-643.

Kale, J. R., Reis, E., \& Venkateswaran, A. (2009). Rank-Order Tournaments and Incentive Alignment: The Effect on Firm Performance. Journal of Finance, 64(3), 1479-1512. doi: 10.1111/j.1540-6261.2009.01470.x

Kiel, G. C., \& Nicholson, G. J. (2003). Board Composition and Corporate Performance: How the Australian Experience Informs Contrasting Theories of Corporate Governance. Corporate Governance: An International Review, 11(3), 189-205. doi: 10.1111/1467-8683.00318

Kolasinski, A. C., \& Li, X. (2013). Can Strong Boards and Trading Their Own Firm's Stock Help CEOs Make Better Decisions? Evidence from Acquisitions by Overconfident CEOs. Journal of Financial and Quantitative Analysis, 48(4), 1173-1206. doi: 10.1017/S0022109013000392

Lazear, E. P., \& Rosen, S. (1981). Rank-Order Tournaments as Optimum Labor Contracts. Journal of Political Economy, 89(5), 841-864. doi: 10.1086/261010

Lee, K., Lev, B., \& Yeo, G. (2008). Executive pay dispersion, corporate governance, and firm performance. Review of Quantitative Finance and Accounting, 30(3), 315-338. doi: 10.1007/s11156-007-0053-8

Lefanowicz, C. E., Robinson, J. R., \& Smith, R. (2000). Golden parachutes and managerial incentives in corporate acquisitions: Evidence from the 1980s and 1990s. Journal of Corporate Finance, 6(2), 215-239.

Lyon, J. D., Barber, B. M., \& Tsai, C. L. (1999). Improved Methods for Tests of LongRun Abnormal Stock Returns. Journal of Finance, 54(1), 165-201. doi: 10.1111/0022-1082.00101

Malmendier, U., \& Tate, G. (2008). Who Makes Acquisitions? CEO Overconfidence and the Market's Reaction. Stanford University: Cambridge, Mass. National Bureau of Economic Research.

Masulis, R. W., Wang, C., \& Xie, F. E. I. (2007). Corporate Governance and Acquirer Returns. Journal of Finance, 62(4), 1851-1889. doi: 10.1111/j.15406261.2007.01259.x

Matolcsy, Z., \& Wright, A. (2007). Australian CEO Compensation: The Descriptive Evidence. Australian Accounting Review, 17(43), 47-59. doi: 10.1111/j.18352561.2007.tb00335.x

Merhebi, R., Pattenden, K., Swan, P. L., \& Zhou, X. (2006). Australian chief executive officer remuneration: pay and performance. Accounting \& Finance, 46(3), 481-497. doi: 10.1111/j.1467-629X.2006.00178.x

Mitchell, M., \& Mulherin, J. (1996). The impact of industry shocks on takeover and restructuring activity. J. Financ. Econ., 41(2), 193-229. 
Moeller, S. B., Schlingemann, F. P., \& Stulz, R. M. (2004). Firm size and the gains from acquisitions. Journal of Financial Economics, 73(2), 201-228. doi: 10.1016/j.jfineco.2003.07.002

Monem, R. M. (2013). Determinants of Board Structure: Evidence from Australia. Journal of Contemporary Accounting \& Economics, 9(1), 33-49. doi: http://dx.doi.org/10.1016/j.jcae.2013.01.001

Morck, R., Shleifer, A., \& Vishny, R. W. (1990). Do Managerial Objectives Drive Bad Acquisitions? Journal of Finance, 45(1), 31-48.

Officer, M. S. (2003). Termination fees in mergers and acquisitions. Journal of Financial Economics, 69(3), 431-467.

Porter, J., \& Singh, H. (2010). What factors drive takeovers in Australia?

Rath, S. (2007). Managerial entrenchment and CEO compensation in Australia. Paper presented at the Oxford Business \& Economics Conference, Oxford University, UK.

Rhodes-Kropf, M., \& Viswanathan, S. (2004). Market Valuation and Merger Waves. The Journal of Finance, 59(6), 2685-2718.

Roll, R. (1986). The Hubris Hypothesis of Corporate Takeovers. Journal of Business, 59(2), 197.

Scharfstein, D., \& Stein, J. (1990). Herd Behaviour and Investment. American Economic Review of Behavioral Finance, 80, 465-479.

Schoenemann, A. (2006). Executive Remuneration in New Zealand and Australia: Do Current Laws, Regulations and Guidelines Ensure Pay for Performance. Victoria U. Wellington L. Rev., 37, 31.

Schultz, E., Tian, G. Y., \& Twite, G. (2013). Corporate Governance and the CEO PayPerformance Link: Australian Evidence. International Review of Finance, 13(4), 447-472. doi: 10.1111/irfi.12012

Schwert, G. W. (2000). Hostility in takeovers: in the eyes of the beholder? The Journal of Finance, 55(6), 2599-2640.

Seo, J., Gamache, D. L., Devers, C. E., \& Carpenter, M. A. (2015). The role of CEO relative standing in acquisition behavior and CEO pay. Strategic Management Journal, 36(12), 1877-1894. doi: 10.1002/smj.2316

Shams, S. M., Gunasekarage, A., \& Colombage, S. R. (2013). Does the organisational form of the target influence market reaction to acquisition announcements? Australian evidence. Pacific-Basin Finance Journal, 24, 89-108.

Shleifer, A., \& Vishny, R. (2003). Stock Market Driven Acquisitions. Journal of Financial Economics, 70, 295-311.

Siegel, P. A., \& Hambrick, D. C. (2005). Pay Disparities Within Top Management Groups: Evidence of Harmful Effects on Performance of High-Technology Firms. Organization Science, 16(3), 259-274. doi: 10.1287/orsc.1050.0128

Simmonds, D. P. (2004). The Impact of Takeover Offer Timing on the Measurement of Australian Bidder Gains: 1976 to 1995. Australian Journal of Management, 29(1_suppl), 1-60. doi: 10.1177/031289620402901S02

Stein, J. C. (1988). Takeover threats and managerial myopia. Journal of Political Economy, 96(1), 61-80.

Stein, J. C. (1989). Efficient capital markets, inefficient firms: A model of myopic corporate behavior. The Quarterly Journal of Economics, 104(4), 655-669.

Wade, J. B., Charles A. O'Reilly, I., \& Pollock, T. G. (2006). Overpaid CEOs and Underpaid Managers: Fairness and Executive Compensation. 17(5), 527-544. doi: $10.1287 /$ orsc. 1060.0204 
Walkling, R. A. (1985). Predicting Tender Offer Success: A Logistic Analysis. $J$. Financ. Quant. Anal., 20(4), 461-478. doi: 10.2307/2330762

Walter, T. S. (1984). Australian Takeovers: Capital Market Efficiency and Shareholder Risk and Return. Australian Journal of Management, 9(1), 63-118. doi: 10.1177/031289628400900105

Wansley, J. W., Lane, W. R., \& Yang, H. C. (1983). Abnormal returns to acquired firms by type of acquisition and method of payment. Financial Management, 16-22.

Weston, J. F., Mitchell, L. M., \& Mulherin, J. H. (2003). Takeovers, Restructuring, and Corporate Governance (4th ed.). New Jersey: Pearson Prentice Hall. 
